DEPARTMENT OF THE INTERIOR

UNITED STATES GEOLOGICAL SURVEY

HOLOCENE MARINE SEDIMENTS ON THE MIDDLE AND OUTER

CONTINENTAL SHELF OF THE BEAUFORT SEA NORTH OF ALASKA

By David A. Dinter

MISCELLANEOUS INVESTIGATIONS SERIES

Published by the U.S. Geological Survey, 1982

G 


\title{
HOLOCENE MARINE SEDIMENTS ON THE MIDDLE AND OUTER CONTINENTAL SHELF OF THE BEAUFORT SEA NORTH OF ALASKA
}

\author{
By David A. Dinter
}

\begin{abstract}
INTRODUCTION
Sheet 1 of this publication depicts the thickness of a presumed Holocene marine sedimentary stratum on the middle and outer continental shelf of the Beaufort Sea north of Alaska. For convenience in this report, the term "Holocene" is applied to any sediments believed to have been deposited on the shelf subsequent to its subaerial exposure during the final Wisconsinan eustatic sea level minimum about 17,000 years ago. Thus the "Holocene" marine stratum contoured here may include, at its base on the outer shelf, sediments older than the formal Pleistocene-Holocene boundary defined at roughly 10,000 years B.P. by Hopkins (1975).
\end{abstract}

Although several sedimentary facies may be present within the contoured unit, it is referred to in this report as a "stratum" because its seismic signature is homogeneous throughout the map area. Beneath most of the middle and outer shelf the base of the contoured stratum is the uppermost prominent sub-seafloor reflector observed on a grid of high-resolution seismic reflection profiles. The age range of the base of the stratum has not been directly or indisputably established because it has never been sampled in the study area. If, however, this highly reflective basal surface formed as a result of being subaerially exposed during the final Pleistocene glacial stage as argued below, then the marine stratum lying depositionally above it must be "Holocene" in the special sense of that term used here.

Sheet 2 of this publication provides structural contours on the base of the inferred Holocene stratum. Data points were obtained by adding the present water depth to each measurement of sediment thickness used to generate the isopach map (sheet 1 ). The results are used in a discussion of the late Quaternary sea level history of the Beaufort Sea.

Owing to the high petroleum potential of sediments underlying the Beaufort shelf a large number of current and completed studies have been devoted to understanding the shelf environment and to delineating the engineering characteristics of its surficial sediments. Details of the late Quaternary sedimentary history of the shelf resulting from the present study cast light on such problems as active faulting and landsliding, thickness of unconsolidated sediment, and depth to subsea permafrost. The results also provide a few more facts to be considered in correlating the sea level history of the Arctic Ocean with the history of formerly nearby Pleistocene ice sheets.

\section{PREVIOUS WORK}

Analyses of modern depositional processes and of the texture and composition of surficial sediments on the
Beaufort shelf were summarized by Barnes (1974), who concluded that active deposition and erosion occur over most of the shelf and that currents and sea ice alternate as important agents of transport. Rodeick (1979) studied the gravels of the outer Beaufort shelf, noting their probable derivation from exotic sources in the Canadian Arctic Islands by ice rafting. Detailed offshore Quaternary stratigraphic work, however, has previously been restricted mostly to the inner shelf, extending from the shoreline out to water depths of roughly $40 \mathrm{~m}$. Reimnitz, Wolf, and Rodeick (1972) provided thicknesses of Holocene marine sediment on the inner Beaufort shelf between Harrison and Camden Bays. Lithostratigraphic sections from four boreholes on the inner shelf north of Prudhoe Bay were published by Chamberlain and others (1978) as part of a study of the distribution and engineering properties of subsea permafrost. Hartz and others (1979) recently presented summary logs of 20 additional cores collected by the U.S. Geological Survey from the inner shelf between the Kuparuk and Canning Rivers. Unfortunately: these cores and the high-resolution seismic data (P. W. Barnes, unpub. data) that tie to them do not overlap our records in any place where the contoured stratum is thick enough to be resolved seismically. Where the data sets do overlap, however, the cores confirm our interpretation that Holocene marine sediment is absent or extremely thin on the inner shelf.

\section{DATA BASE AND REDUCTION TECHNIQUES}

The base of the inferred Holocene sedimentary stratum on the outer and middle shelf was identified and measured on a network of high-resolution seismic reflection profiles collected roughly perpendicular to the shelf break at approximately $18-$ to $35-\mathrm{km}$ intervals across the entire Alaskan Beaufort Sea continental margin and tied by several lines subparallel to the coast (sheet 1 ). The Uniboom seismic system used employs a $1-\mathrm{kHz}$, hull-mounted sound source. Our high-resolution data extend from about the $25-\mathrm{m}$ isobath seaward to the penetration limit of the Uniboom system at about 800-m water depth on the upper continental slope. Owing to geologic factors, however, the contoured stratum is not mappable beneath water deeper than about 60 to $90 \mathrm{~m}$.

A sound velocity of $1,500 \mathrm{~m} / \mathrm{s}$ has been used to convert seismic traveltimes through the inferred Holocene stratum to the sediment thicknesses contoured on the map. This choice is based on interval velocities derived from multichannel seismic reflection data and on refraction velocities taken from sonobuoy profiles collected simultaneously with the high-resolution data (Robert Houtz, written commun., 1980). Assuming a slightly 
higher sedimentary sound velocity of $1,600 \mathrm{~m} / \mathrm{s}$, which may be more accurate in some places, yields thickness estimates only about $4 \mathrm{~m}$ greater than those shown on sheet 1 in the thickest parts of the inferred Holocene stratum. In general, this stratum cannot be resolved where it is less than about $5 \mathrm{~m}$ thick because its base is then obscured by the trailing oscillations of the Uniboom sonic pulse.

All isopachs south of and including the zero-meter isopach between Cape Halkett to the west and Canning River to the east are taken from Reimnitz and others (1972) and from Reimnitz (unpub. data). These data were collected with a medium-resolution arcer system, and a sound velocity of $1,500 \mathrm{~m} / \mathrm{s}$ was used to convert traveltimes to sediment thicknesses. Since none of these profiles crosses any of those analyzed in the present study, it is unknown whether the basal reflectors measured in each case are strictly correlative. Reimnitz' isopachs have been included on sheet 1 , however, in order to present as complete a compilation of Holocene sediment thickness on the Beaufort shelf as is currently possible.

\section{OBSERVATIONS AND DISCUSSION}

LATE QUATERNARY STRATIGRAPHIC MODEL

Figure 1 depicts a generalized cross section of presumed late Quaternary sediments on the middle and outer Beaufort shelf north of Alaska. The seabed, variably disrupted by ice gouges, is directly underlain by a marine stratum less than $5 \mathrm{~m}$ to more than $45 \mathrm{~m}$ thick (unit $A$ on fig. 1 ). Unit $A$, the thickness of which is contoured on sheet 1 , appears as an acoustically translucent layer on the high-resolution profiles, displaying only vague, continuous, internal bedding subparallel to the seafloor. Unit $A$ is bounded at its base by a strong, continuous reflector which shows much evidence that it was once exposed subaerially. The basal surface is cut locally by very shallow channels and by low terraces that presumably formed during brief still-stands superimposed on a marine transgression.
The former subaerial surface is underlain directly by either unit B or unit C. Unit B comprises a discontinuous, internally structureless, hummocky-topped layer of sediment that, where it is present, tends to thicken seaward. This stratum is interpreted to be mostly nonmarine, and may include both outwash derived from glaciers in the Brooks Range to the south and ice-rafted sediments from sources in arctic Canada (Rodeick, 1979), as well as alluvium deposited by streams that traversed the shelf during a period of subaerial exposure. Beneath much of the eastern third of the outer shelf, unit B terminates seaward in a discontinuous ridge of sediment about 1 to 3 $\mathrm{km}$ wide and 8 to $18 \mathrm{~m}$ thick at its apex. The ridge is roughly parallel to the present shelf break and extends laterally for more than $150 \mathrm{~km}$. It was probably deposited as a sediment-laden tongue of glacial ice melted along the margin of the formerly exposed shelf. Such an ice tongue would have emerged from northwestern Canada, because glaciers originating in the Alaskan Brooks Range never extended northward as far as the present Alaskan Beaufort shelf (Hamilton and Porter, 1975).

Unit $C$ is a marine stratum that directly underlies either unit $B$ or unit $A$, depending on whether unit $B$ is present: Where neither unit $B$ nor unit $A$ is present, unit $C$ is thought to crop out at the seafloor. Acoustically, unit $C$ appears very similar to unit $A$, except that its internal bedding is slightly more prominent in places.

\section{AGE ASSIGNMENT}

From the Canadian border westward to at least $146^{\circ} \mathrm{W}$., the longitude of the mouth of Canning River, much of the middle and outer shelf appears to be a site of active deposition, or at least an area where marine sediment has been deposited since the latest subaerial exposure of the shelf. Surficial sediment samples from the top of unit $A$ in this area are composed mainly of unconsolidated marine silt and mud but contain varying amounts of clay, fine sand, gravel, and organic material as well (Barnes, 1974).

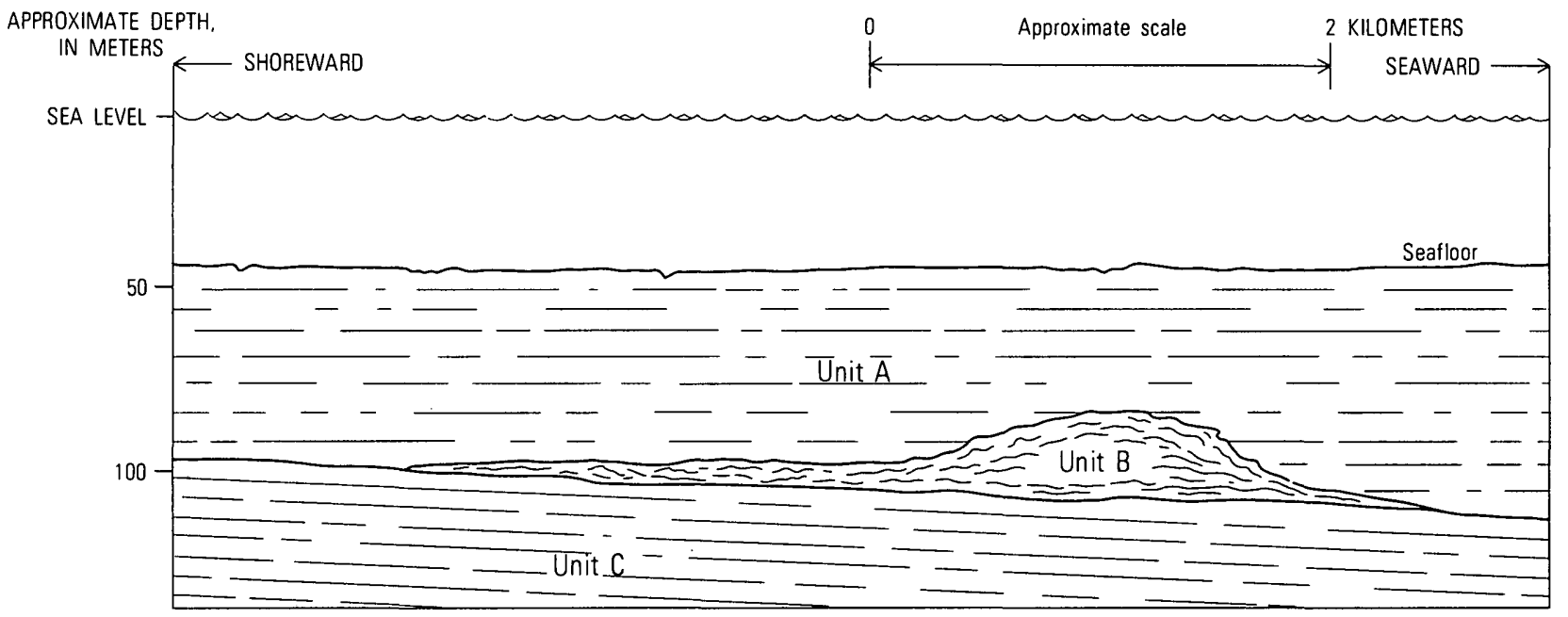

Figure 1.-Idealized cross section of presumed late Quaternary sediments on the middle and outer shelf of the Beaufort Sea north of Alaska. Unit $\mathrm{A}$ is interpreted to be Holocene marine, unit $\mathrm{B}$ to be middle and late Wisconsin nonmarine and marine, and unit $\mathrm{C}$ to be early Wisconsin or older marine 
The continuous, parallel bedding and acoustic homogeneity of unit $A$ suggest that it represents an episode of virtually uninterrupted marine deposition. Since surficial sediment samples, as noted above, indicate that this depositional episode is presently, or was recently, active, the former subaerial surface at the base of unit $A$ must be a disconformity representing the most recent subaerial exposure of the shelf. This exposure occurred during the late Wisconsin sea level lowstand that culminated at approximately $-100 \mathrm{~m}$ about 17,000 years ago (Dillon and Oldale, 1978). Since it directly overlies the late Wisconsin disconformity, unit $A$ is tentatively assigned a Holocene age.

Assuming this interpretation to be correct, unit B is probably a nonmarine and shallow marine unit that accrued during the late Wisconsin glacial stage and unit $C$ is a marine stratum deposited during either the midWisconsin interstadial (oxygen isotope stage 3 , Shackleton and Opdyke, 1973), or the previous interglacial stage (oxygen isotope stage 5).

\section{CHARACTERISTICS OF THE HOLOCENE STRATUM}

Over much of the eastern third of the shelf the Holocene marine stratum (unit $A$ on fig. 1) forms a wedge that thickens seaward to local maxima greater than $45 \mathrm{~m}$ near the inner shelf break. This geometry contrasts markedly with a pattern typically observed on other passive margins, where Holocene marine sediments are commonly thickest on the inner and middle shelves, and relict Pleistocene deposits are exposed at the seafloor on the outer shelf (e.g., Curray, 1965). The base of the Holocene stratum has an average seaward dip of $0.08^{\circ}$; the top of the stratum dips seaward at an average of $0.03^{\circ}$.

Although the seaward-thickening wedge shape is also apparent on the western two-thirds of the shelf, Holocene sediments appear to be much thinner there, in general, than in the east, attaining a maximum thickness no greater than $25 \mathrm{~m}$. In addition, the basal Holocene disconformity is much less clearly distinguishable seismically west of about long. $146^{\circ} \mathrm{W}$. than it is to the east. Apparently, the sedimentary processes such as subaerial erosion and deposition, which resulted in a strong acoustic contrast at the level of the disconformity on the eastern shelf, were less active on the western shelf, perhaps as a result of its much greater distance from streams emanating from the Brooks Range. Another possibility is that the sediments underlying the disconformity on the western shelf are of a different texture or are less consolidated than those underlying it on the eastern shelf.

The relative paucity of Holocene sediment on the western shelf may be due in part to the remoteness of this area from the Mackenzie Delta and Brooks Range sediment sources, and in part to a postulated Pleistocene shelf elevation that was higher in the west than in the east (sheet 2). The relative depression of the eastern shelf may derive from its former proximity to a lobe of the Laurentide Ice Sheet that extended seaward from Mackenzie Valley (Prest, 1968).

The ideal wedge shape of the Holocene stratum is disrupted on the eastern shelf by a zone of uplift north and northeast of Camden Bay (sheet 1). This zone is characterized by active seismicity and negligible Holocene sediment cover.
SEA LEVEL HISTORY

East of about long. $146^{\circ} \mathrm{W}$., the basal Holocene disconformity terminates along a line where it lies about 97 to $115 \mathrm{~m}$ below present sea level. The disconformity is mantled here by at most 45 to $55 \mathrm{~m}$ of marine sediment. Seaward of this line, the shelf was apparently not exposed subaerially during the late Wisconsin glacial maximum. Sediments seaward of the termination show vague, continuous bedding at least as deep as 150 to $200 \mathrm{~m}$ beneath the seafloor, and probably represent nearly continuous marine deposition from at least middle Wisconsin through Holocene time.

If the basal Holocene reflector formed mainly as a result of processes related to subaerial exposure, then its seaward termination roughly outlines the northernmost Wisconsinan coastline, and its terminal depth approximates the maximum late Wisconsin sea level lowstand. The variability of the terminal depth from line to line may indicate that the shelf has been slightly warped since its latest subaerial exposure. The range of terminal depths on the Beaufort shelf, 97 to $115 \mathrm{~m}$, is in good agreement with the most widely accepted estimates of maximum late Wisconsin sea level lowering obtained elsewhere (e.g., Curray, 1965; Dillon and Oldale, 1978).

The structural contours shown on sheet 2 of this publication illustrate the present morphology of the surface that was exposed subaerially during the late Wisconsin glacial maximum. In general, this surface is inclined gently seaward at a slope of about $0.08^{\circ}$, but it steepens abruptly near the late Pleistocene shoreline. The surface was traversed by one major channel northeast of Smith Bay, near the western edge of the map area, but no continuation of this feature has been located on the inner shelf.

Assuming that relatively minor isostatic subsidence or rebound has occurred since the end of the late Wisconsin glacial stage on the Beaufort shelf, the structural contours (sheet 2) may be used in conjunction with a standard sea level curve (e.g.,Shackleton and Opdyke,1973) to estimate paleoshoreline positions corresponding to given times during the late Quaternary transgression, thereby approximately dating the base of the Holocene marine stratum in any given location.

\section{IMPLICATIONS OF HOLOCENE STRATIGRAPHY TO ENVIRONMENTAL GEOLOGY}

Patterns of Holocene sedimentation on the Beaufort continental shelf provide information applicable to at least four environmental considerations-active tectonic zones, active sliding and slumping, thickness of unconsolidated sediment, and a plausible minimum depth to the top of subsea permafrost-which will be crucial to the engineering of oil and gas recovery structures.

ACTIVE TECTONISM

Nearly all earthquakes recorded from the Alaskan Beaufort shelf have epicenters within the broad, arcuate zone marked by negligible Holocene sediment cover north and northeast of Camden Bay (Grantz and Dinter, 1980). Active reverse and normal faulting there has disrupted the seabed, leaving scarps with as much as $6 \mathrm{~m}$ of relief, and 
the basal Holocene disconformity is arched about 10 to 25 $m$ above its mean level elsewhere on the eastern third of the shelf. The tectonic arch is not delineated by the bathymetry because its flanks have been mostly covered by Holocene sediment.

North of Demarcation Bay a small basin has apparently accumulated more than $20 \mathrm{~m}$ of sediment along its west-northwest-trending axis since the late Wisconsin sea level lowstand. A slightly concave shape of the seabed above the basinal axis suggests that subsidence is either active now or was recently active. Northwest of this basin a terrane of anomalously thin Holocene sediment overlies a broad regional arch developed in older Cenozoic sediments. The report of one earthquake from this terrane suggests that it may still be tectonically active.

ACTIVE SLIDING AND SLUMPING

Much of the Beaufort outer shelf and upper slope seaward of the $50-\mathrm{m}$ isobath is disrupted by a bedding-plane slide terrane containing, in places, narrow, open crevasses as deep as $17 \mathrm{~m}$. Further seaward there are rotational slump terranes in which huge slump masses break along listric (concave upward) surfaces and slide downslope at high angles (Grantz and Dinter, 1980).

On the western outer shelf, sliding is inferred to be active because tabular bedding-plane slides disrupt Holocene marine sediments there and breach the seafloor in areas where sedimentation is probably active. Sliding is also inferred to be active on the eastern outer shelf. The eastern extent of the slide terrane lies seaward of the basal Holocene disconformity and hence beyond the line where a discrete Holocene stratum may be seismically delineated; however, the uppermost sediment in the eastern slide terrane appears to correlate with Holocene marine sediment that is more than $40 \mathrm{~m}$ thick just inshore of the disrupted area.

\section{UNCONSOLIDATED SEDIMENTS}

Surface samples of the Holocene stratum are unconsolidated (Barnes, 1974). The very low-angle bedding-plane slides developed in the sediments of this layer indicate that these deposits probably have very low resistance to shear. Unconsolidated Holocene deposits are probably especially unstable just outside the perimeter of the active seismogenic terrane northeast of Camden Bay, where failure may be triggered by earthquakes, and along the shelf break, where large-scale slumping may induce failures in the thick, unconsolidated silt and mud on the outer shelf.

\section{PERMAFROST}

Wherever permafrost occurs in sediments that were not fully compacted prior to freezing, particular care must be taken during drilling to avoid melting. Such sediments may compact upon being thawed and exert drag on conventional drill casings, causing failure (Howitt, 1971). Permafrost that formed on the Beaufort shelf during the late Wisconsin sea level lowstand was probably originally very thin on the outer shelf, which was exposed subaerially only relatively briefly, and was perhaps as thick as $300 \mathrm{~m}$ on the inner shelf, which was exposed for many thousands of years (Mackay, 1972). The original accumulation has likely warmed and partially melted since reinundation of the shelf, but the present distribution of relict Pleistocene permafrost is unknown over most of the Alaskan Beaufort shelf. A probable minimum depth to its top is provided by the Holocene sediment isopachs, however, since it is unlikely that permafrost aggraded upward from frozen Pleistocene sediments into the relatively warm, saline marine mud and silt deposited during the late Quaternary transgression of the sea.

\section{CONCLUSIONS}

A study of the thickness and distribution of Holocene marine sediments on the shelf of the Beaufort Sea has provided results applicable to the Quaternary geologic history and environmental geology of the continental margin north of Alaska. The data are presented in two contour maps, one showing isopachs on the Holocene marine stratum and the other providing structural contours on the basal Holocene disconformity. Conclusions based on an examination of these maps may be summarized as follows:

1. Much of the middle and outer shelf of the Beaufort Sea has been an active site of marine deposition since near the beginning of the latest (late Wisconsin and Holocene) transgression of the sea. The total thickness of Holocene marine sediment near the inner shelf break on the eastern third of the shelf exceeds $45 \mathrm{~m}$.

2. Prior to the latest transgression most of the shelf was exposed subaerially. The formerly exposed surface is now a basal Holocene disconformity. The seaward limit of this disconformity marks roughly the northernmost late Wisconsin coastline, and the structural depth of its termination, about 97 to $115 \mathrm{~m}$, approximates the lowest sea level stand during the late Wisconsin glacial maximum.

3. Holocene marine sediments are substantially thinner on the western two-thirds of the shelf than on the eastern third, possibly owing in part to a postulated late Pleistocene elevation difference between these two areas.

4. The arcuate zone northeast of Camden Bay, characterized by negligible Holocene sediment cover, marks a terrane of Holocene uplift related to active, seismogenic reverse and normal faulting. In general, uplifting areas of the shelf are marked by thin or absent Holocene sediment, and relatively depressed or subsiding areas by thicker Holocene sediment.

5. The assignment of a late Holocene age to marine sediments near the shelf break implies that bedding-plane slides which disrupt the uppermost, also presumably late Holocene, sediments of the outer shelf and upper slope must be presently active.

6. Isopachs on the Holocene stratum provide a minimum thickness of unconsolidated sediments with very low shear strength.

7. The Holocene sediment isopachs provide a probable minimum depth to the top of subsea permafrost that formed during late Wisconsin subaerial exposures of the shelf. 


\section{REFERENCES CITED}

Barnes, P. W., 1974, Preliminary results of marine geologic studies off the northern coast of Alaska, in Hufford, G. L., Fortier, S. H., Wolfe, D. E., Doster, J. F., Noble, D. L., Barnes, P. W., Weiss, H. V., Chew, Ken, Guttman, M., Host, A., Naidu, A. S., and Mowatt, T. C., 1974, Websec 71-72, An ecological survey in the Beaufort Sea: Washington, D.C., U.S. Coast Guard Oceanographic Unit, Oceanographic Report No. CG-373-64, 268 p.

Chamberlain, E. J., Sellmann, P. V., Blouin, S. E., Hopkins, D. M., and Lewellen, R. I., 1978, Engineering properties of subsea permafrost in the Prudhoe Bay region of the Beaufort Sea: International Conference on Permafrost, 3d, Edmonton, Alberta, Canada, July 10-13, Proceedings, p. 629-635.

Curray, J. R., 1965, Late Quaternary history, continental shelves of the United States, in Wright, H. E., and Frey, D. G., eds., The Quaternary of the United States: Princeton, N.J., Princeton Univ. Press, p. 723-735.

Dillon, W. P., and Oldale, R. N., 1978, Late Quaternary sea level curve: reinterpretation based on glaciotectonic influence: Geology, v. 6, p. 56-60.

Grantz, Arthur, and Dinter, D. A., 1980, Constraints of geologic processes on petroleum development in the western Beaufort Sea: International Conference and Exhibition, Petroleum and the Marine Environment, Monaco, May 27-30, 1980, Proceedings (in press).

Greenburg, Jonathan, Hart, Patrick E., and Grantz, Arthur, 1980, Bathymetric map of the continental shelf, slope and rise of the Beaufort Sea north of Alaska: U.S. Geological Survey Miscellaneous Investigations Series Map I-1182-A, scale 1:500 000.
Hamilton, T. D., and Porter, S. C., 1975, Itkillik glaciation in the Brooks Range, northern Alaska: Quaternary Research, v. 5, p. 471-497.

Hartz, R. W., Holden, K., Hopkins, D. M., and Shearer, G., 1979, Location map and summary logs for the U.S. Geological Survey's 1979 Beaufort Sea over-the-ice drilling program: U.S. Geological Survey Open-File Report 79-1303, 33 p.

Hopkins, D. M., 1975, Time-stratigraphic nomenclature for the Holocene epoch: Geology, v. 3, January 1975, p. 10.

Howitt, Frank, 1971, Permafrost geology at Prudhoe Bay: World Petroleum, v. 42 , no. 8 , p. 28-32.

Mackay, J. R., 1972, Offshore permafrost and ground ice, southern Beaufort Sea, Canada: Canadian Journal of Earth Sciences, v. 9, p. 1550-1561.

Prest, V. K., compiler, 1968, Glacial map of Canada: Geological Survey of Canada Map 1253A, scale 1:5,000,000.

Reimnitz, Erk, Wolf, S. C., and Rodeick, C. A., 1972, Preliminary interpretation of seismic profiles in the Prudhoe Bay area, Beaufort Sea, Alaska: U.S. Geological Survey Open-File Report no. 1806, 11 p.

Rodeick, C. A., 1979, The origin, distribution, and depositional history of gravel deposits on the Beaufort Sea continental shelf, Alaska: U.S. Geological Survey Open-File Report 79-234, 87 p., 31 figs.

Shackleton, N. J., and Opdyke, N. D., 1973, Oxygen isotope and paleomagnetic stratigraphy of equatorial Pacific core V28-238: oxygen isotope temperatures and ice volumes on a $10^{5}$ and $10^{6}$ year scale: Quaternary Research, v. 3, p. 39-55. 